\title{
Queer Desire in Japanese TV Series
}

\author{
Jasmin Rückert
}

\begin{abstract}
This article provides an analysis of representations of sexual minorities in Japanese TV series. It outlines how homosexual and queer desire is depicted and how stereotypes and tropes are used in the construction of queer characters in this media format. The article also illuminates the ways in which TV series differentiate between depictions of same-sex romance and opposite-sex romance. The corpus of analysed TV series spans a period of twenty-five years. Thus, the analysis also sheds light on changes in the representation of sexual minorities over time. Examples from recent TV series point to a more positive and sometimes didactic approach towards the topic of homosexuality in Japanese mainstream media.
\end{abstract}

Keywords: Queer, LGBT, television series, terebi dorama, discourse.

Rückert, Jasmin. 2019. "Queer desire in Japanese TV series." 


\section{Introduction}

When Toranjitto gāruzuトランジットガールズ (Transit Girls) aired on Fuji TV in 2015, it gained a lot of media attention for supposedly being the first Japanese TV series depicting a love-story between two girls. Online media in Japan, but also international media and especially media dedicated to LGBT (lesbian, gay, bisexual, and transgender)-related news like Gaystarnews, Pridelife, Pinknews, Afterellen and Straight, reported "Japan's first lesbian drama" (News Team 2015). Many of the international reactions added comments about Japanese society being "conservative" (e.g., Wee 2015) to this announcement and appeared to perceive the news about the series as a sign of progress in a unilinear history of progress of LGBT rights. To my knowledge, Toranjitto gāruzu was indeed the first TV series to centre on a love relationship between two girls who are the series' main characters. However, many representations of same-sex desire and gay, lesbian or bisexual characters have been shown in Japanese TV series prior to Toranjitto gāruzu. The TV series I am going to discuss in this article feature major and minor characters who can be identified as queer. These include female and male characters as well as characters whose gender identity remains ambivalent. In some of the series, same-sex attraction is presented through characters with a clearly defined sexual orientation. In other series, feelings of same-sex attraction are shown as exceptional and not exemplary for a characters' sexual orientation. This article aims to analyse predominant tendencies in representations of queerness in a Japanese context.

\section{State of Research}

The academic field of Gender Studies tends to put emphasis on the power of representation, the importance of popular culture, and its subversive potential. However, a Eurocentric focus on US-American popular cultural products in previous research left a blank space where Northeast Asian cultural products are concerned. In the field of research on Japanese popular culture, transgressions of gender and sexuality are a recurring point of interest for scholars, mostly with a focus on manga and anime (Mae et al 2016: 5-6). Since the 1990s, TV series have also been considered valuable sources for the evaluation of gendered stereotypes and gendered role models (see Gössmann 1997; Saito 2007; Freedman and Iwata-Weickgenannt 2011; Kunihiro 2012; Darlington 2013; Mithani 2014; Dales 2015; Scherer 2016; Kanemoto and Collins 2017). However, the depiction of sexual minorities in Japanese TV series has been a topic largely overlooked so far. Most attention has been paid to the TV series Rasuto furenzu ラスト・フレンズ (Last Friends) (Yuen 2011; Nakamura 2008; Görlach 2011; Nim 2013) and Dōsōkai 同空会 (Class Reunion) (Miller 2000; Dobbins 2000) with sometimes contrasting results regarding the evaluation of queer representations. 
Tomoe Kentarō 巴健太郎 chose a comparative approach and found tropes of effeminate gay men in a number of TV series after 2000 (Tomoe 2014). To my knowledge, however, no study has been conducted yet that critically researches representations of same-sex desire of different genders in a larger number of Japanese TV series from a diachronic perspective. This article aims to bridge results from both Gender Studies and Japanese Studies and provide new insights to the field of Japanese popular culture.

\section{Queer Theory and Categories of Sexual Orientation and Gender}

In this analysis, I examine expressions of same-sex intimacy and desire in Japanese TV series through the lens of Queer Theory. The decision not to simply talk about representations of "lesbians" or "gay men," but often (sometimes additionally) referring to the term "queer" is a conscious one. For the early Queer theorist Eve Sedgwick, the term "queer" refers to "the open mesh of possibilities, gaps, overlaps, dissonances and resonances, lapses and excesses of meaning when the constituent elements of anyone's gender, of anyone's sexuality aren't made (or can't be made) to signify monolithically" (Sedgwick 1998: 208). An important aspect of Queer Theory is the analysis of power relations within heteronormative societies (Wagenknecht 2007: 18). In Queer Theory, the stability of the gender binary but also the stability of fixed categories of sexual orientation are called into question. The re- and deconstruction of these categories are objects of analysis in research based on Queer Theory. At the same time, sexualities that do not fit into or are devalued in a heteronormative framework call for a terminology to describe the desires, feelings and practices. The terms and words used to describe non-normative desire each come with a history of their own. Therefore, the study of Japanese popular culture must also take into consideration how categories like sexuality and gender are referred to in Japanese language and how they relate to the terms commonly used in English. It is also important to be aware of the underlying discourses regarding changes in terminology.

Japanese Studies scholars are often confronted with remarks on sexualities in Japan being less defined than in the 'West.' The usage of gairaigo 外来語 (foreign language terms) such as rezubian レズビアン (from the English word "lesbian”), gei ゲイ (from “gay”) or kuīaクイーア (from “queer”) seem to enhance the understanding that definitions of sexual categories are imported products. Certainly, the understanding of sexualities in Japan as it is today was influenced by what Suganuma Katsuhiko 菅沼勝彦 calls “cultural flow” (2016: 244). However, Diana Khor warns against viewing the results of cultural exchange as having eradicated a uniquely Japanese perspective of gender and sexuality as transgressive categories (2005: 50). She suggests instead to critically interrogate the existence of a supposedly coherent Western sexual identity, which often serves as the point of reference in discussions about sexuality in Japan (ibid: 51). Through such an interrogation, it can be shown that the perception 
of a coherent and stable 'Western sexual identity' is itself not tenable. In pursuing a critical investigation of power relationships, the adoption of 'Western' terminologies and concepts in Japan are often challenged. In general, attempts to deconstruct the idea of supposedly coherent and clearly defined (cultural and / or gendered) identities are part of both academic and queer activists' discourse. In this context, Queer Theory scholar Shimizu Akiko 清水明子 asks whether one ought to look for an indigenous "Japanese Queerness." However, she negates this and concludes that to simply deconstruct and disregard the categories in use might lead to a lack of solidarity with the people for whom these categories are of relevance:

The question is not merely what you identify with, or whether or not you choose to identify with a certain existing category. What is at stake is whether or not you are identified as something, or more precisely, what you are identified as (Shimizu 2007: 508).

With these considerations in mind, I will use the terms same-sex, gay, lesbian, or bisexual as well as queer to describe the images of desire, sexual, and romantic practices and categories of identification I encounter in the analysed TV series. I apply the terms according to their usage in the series or as used by people involved in the production of the series, although sometimes it is impossible to be accurate. This is especially the case when the fictional TV-characters' self-description includes otherwise derogatively used terms. In this article, the term "queer" does not merely refer to same-sex intimacy or homosexuality; rather, by using this term, I want to place emphasis on the fact that there is a multiplicity of sexualities / sexual orientations, encompassing gay, bisexual, and other (sometimes ambivalent and fluid) forms of gender identities which go beyond the established categories.

\section{Queer Visibility}

The question of the presence of same-sex desire as a topic in Japanese TV series is linked to the question of the visibility of queer people in the Japanese public and mainstream media in general. Visibility is a buzz phrase widely used in discussions about the inclusion or exclusion of sexual and other minorities in cultural products, but also in the public sphere of society. While being rendered invisible is understood as devaluing and sometimes endangering minorities, there are also dangers in making minorities visible. Undeniably, visibility is an important aspect when attempting to enhance the rights of sexual minorities, but it does not necessarily equate political presence or power, agency, or access to resources and privileges (Schaffer 2008: 12). Furthermore, it can also include discriminatory representations. It is therefore important not only to analyse in which quantity someone or something is represented, but also to ask how someone or something is represented. 
In the demand for visibility for visibility's sake lies a danger of accepting or being content with representations which might actually stabilise the hegemonic order; certain forms of representation may also be counterproductive to other demands of queer lives (ibid: 12). The processes in which minoritised subject positions are made visible often include references and quotes that affirm their minoritised position. For example, the representation of a queer person as suffering as a result of being queer may evoke sympathy, but sets that person apart from non-queer people depicted in the same context. It is therefore necessary to ask what is perceived as queer, in which contexts these images are produced, and how they are juxtaposed against heteronormative images.

Such images cannot simply be understood as a binary of positive and negative representations. The Queer media researcher Amy Villarejo sees a need to question the effects of seemingly positive images. In the US-American context, she finds seemingly "positive" portraits of gay people frequently being depicted as, for example, sanitised, desexualised, normative, whitened, lightened, or otherwise well-behaved folks accommodating a liberal embrace (Villarevo 2007: 390). In the German-speaking context of queer images in television, Sushila Mesquita, a scholar of Queer Theory, criticises tendencies of normalisation as well as carnevalisation as a result of a neoliberal tolerance of pluralism which inadvertently also enhances the depoliticisation of queer causes (2008: 134). My article asks whether similar portrayals of queerness can be found in the Japanese context as well.

\section{Queer Visibility in Japanese Mainstream Media}

This section introduces some important developments over the course of the last twenty-five years as well as some of the genres that highlight queerness. The genres "Boys Love" (bōizu rabu ボーイズラブ) (BL) and "Yuri” (百合) are of special importance because of their immense popularity both within and beyond Japan. BL and Yuri are complex genres that evoke mixed reactions. They are very present in manga and anime products and depict sexual and romantic relations between men (BL) or women (Yuri). Since the 1970s, BL has been a subgenre of the shōjo 少女 genre, which is aimed primarily at a young female audience, but has now reached a mainstream audience (Welker 2015: 43). Interestingly, the consumers as well as writers of BL and Yuri respectively are often not gay women or men, but people who do not necessarily identify as being queer (McLelland 2015).

While some research has been conducted on BL, only a few studies have analysed the representations of female-to-female intimacy in Yuri. Common criticism of the BL genre includes the misrepresentation of gay men by relying on young, effeminate, and beautiful characters (bishonen 美少年) and/or binary gender-roles in the depiction of gay pairings. Both genres limit the view on homosexuality by either overemphasising erotic aspects (BL) or omitting them (Yuri). However, Japanese Studies 
researcher Verena Maser found that despite harsh criticism from lesbian women about the Yuri genre, there is also a considerable number of queer-identified female fans of this genre (2013: 155). For researcher Claire Maree, the "consumption of Yuri as well as of BL (boys' love) and Sho-jo (girls') manga is an essential element of queer women's culture" (2015: 236). In popular media like manga and anime, boundary transgressions of gender and sexualities appear to have a stronger presence than in other media, and this allows for making queer bodies visible, which are otherwise left out of the picture. Nevertheless, the (new) images can often not be transported into the sphere of everyday life; instead, they seem to be restricted to the sphere of the imagination.

Other media formats need to be taken into consideration as well as indicators of queer visibility in mainstream media. The 1990s, in which the earliest TV series I am going to discuss was broadcast, aligned with a rise of gay visibility in Japan that was marked by the publication of autobiographies, interviews and discussions about homosexuality in newspapers and magazines. This period is sometimes labelled as a "gay boom" (McLelland 2000: 29; Sugawa 2015: 101). Lesbian representations were much scarcer. However, James Welker points out that depictions of gay male characters were also used by women as a source of information about homosexuality (2010: 367). The presence of LGBT-related topics in Japanese mainstream media rose further in the 2000s, as Kawaguchi Kazuya 河口和也 observed. The researcher welcomed the effect of a strengthened visibility of LGBT-related topics in the media as it enabled more people to "come out" to their families and friends (Kawaguchi 2010: 151). However, Kawaguchi places this development in the context of neoliberalism, the discovery of members of the LGBT community as consumers, and the growing overall consumerism of what is perceived as queer. The commercialism can be applied especially to the presence of drag queens (one-kyaraオネエキャラ) as entertainers on Japanese television shows and entertainment programmes (ibid: 159-161). Now-popular drag performers have in fact a longer history than one might expect and have been present in Japanese entertainment industries and TV shows since the 1950s (Maree 2015: 98). These media productions tend to show effeminate men whose sexual orientation is implied to be gay but who are not enjoying either romantic or sexual relationships. Gender researcher Mitsuhashi Junko 三橋順子 voiced similar criticisms (2009: 23), and Suganuma Katsuhiko states that "Japanese queer male culture has been made consistently visible in a curious fashion to the gaze of the mainstream Japanese public, to titillate their voyeuristic curiosity" (2007: 490). 


\section{Selection and Analysis of Japanese TV Series}

The TV series I am going to discuss aired on different Japanese television channels over the last twenty-five years. The following series were selected for analysis:

- That Time My Heart Got Stolen (Sono toki hāto wa nusumareta その時ハート は盜まれた), Fuji TV, 1992.

- The Devils' Kiss (Akuma no Kiss 悪魔のKISS), Fuji TV, 1993.

- Class Reunion (Dōsōkai 同空会), Nippon TV, 1993.

- Living Alone (Hitorigurashi ひとり暮らし), Tokyo Broadcasting System, 1993.

- Whitebook Asunaro (Asunaru hakusho あすなろ白書), Fuji TV, 1996.

- Romance (Romansu ロマンス), Nippon TV, 1999.

- The Melancholy of Age Twenty-Nine - Paradise Thirty (29-sai no yüutsu paradaisu sātī 29歳の憂うつパラダイスサーティー), TV Asahi, 1996.

- Love Complex (Rabu konpurekkusu ラブコンプレックス), Fuji TV, 2000.

- Loving Mom More Than Anyone Else (Dare yori mo mama o aisu 誰よりもマ マを愛す), Tokyo Broadcasting System, 2006.

- Nodame Cantabile (のだめカンタービレ), Fuji TV, 2006.

- Last Friends (Rasuto furenzu ラスト・フレンズ), Fuji TV, 2008.

- What the School Cannot Teach! (Gakkō ja oshierarenai! 学校じゃ教えられ ない!), Nippon TV, 2008.

- Love Collection Tokyo (Rabu kore Tōkyō ラブ•コレ 東京), Gyao, 2008.

- BOSS, Fuji TV, 2009.

- Last Cinderella (Rasuto Shinderera ラストワシンデレラ), Fuji TV, 2013.

- Fake Couple (Gisō no füfu 偽装の夫婦), Nippon TV, 2015.

- Transit Girls (Toranjitto gāruzuトランジットガールズ), Fuji TV, 2015.

- Ants without Umbrellas (Kasa o motanai aritachi wa 傘をもたない蟻たちは), Fuji TV, 2016.

The earliest series of the sample aired in 1992. However, depending on how openly one wants to define same-sex desire and intimacy, one can find examples as early as the 1968 TV series Ōoku (大奥, The Inner Chambers), which has since had many reruns. More difficult to discover are examples of romantic yet platonic relationships between characters of the same gender and TV series in which a homoerotic or homoromantic subtext can be deciphered - by those who are able to see it. The series I chose for my analysis share the commonality of having same-sex desire as a main aspect of the narrative. Another reason for selecting the series is their popularity, which I identified through both viewership numbers as well as references in secondary literature and in queer online-media. The format of the TV series can be classified as renzoku dorama 連続ドラマ or simply dorama (ドラマ), a Japanese term for TV series 
with usually between nine and fourteen episodes; the specific productions belong to different sub-genres such as romance or comedy. I excluded historical dramas and science fiction from my sample as the aim was to focus on TV series that depict realistic situations based on every-day experiences of LGBT people in contemporary Japan.

The analysis takes the form of a contextualised media analysis based on guidelines developed by Lothar Mikos (2008) and Sascha Trültzsch (2009). The analytical process focused on content and discursive context rather than on aesthetical representations. I developed three sets of questions to determine how the TV series constitute meaning: the first focused on the queer characters and their role in the narrative structure, the second concerned the representation of queer desire and a possible differentiation between queer and non-queer desire, and the third aimed to highlight references to discourses about queerness in Japanese media and society.

After a first viewing of the series, it became apparent that the depiction of samesex desire varied greatly depending on the gender of the characters involved. While some characters' gender identities were shown as ambivalent, an apparent distinction remained between cisgender-men ${ }^{1}$ and their queer desire, and desire that could be read as lesbian desire. To demonstrate these findings, I will first introduce some series depicting male same-sex desire before moving on to the representation of lesbian desire. The series I have selected as examples all feature queer people as recurring characters. A discussion of the relevant series will be preceded by brief summaries of the series' narratives. In the last part of this article, I will point out commonalities in the depictions of both gay and lesbian as well as other forms of queer desire. The following sections will reference a greater number of series from the wider sample without giving a summary for each.

\section{Series Depicting Male Same-Sex Desire}

I will first focus on four series that show male main characters who can be read as gay: Dōsōkai, Dare yori mo mama o aisu, Gakkō ja oshierarenai, and Gisō no füfu.

One of the TV series most often called upon as representative of the depiction of queer lives in Japanese television in Japanese Studies literature is Dōsōkai (for example, see Dobbins 2000; Miller 2000; and Gössmann 2016). The series is often mentioned as an example of the rising visibility of queerness in lieu of the already mentioned so-called "gay boom" of the 1990s. Dōsōkai depicts the lives of a group of young adults with a focus on the recently married couple Ando Fūma (portrayed by Nishimura Masahiko 西村まさ彦) and Ando (formerly Onihara) Natsuki (portrayed

\footnotetext{
${ }^{1}$ Cisgender and the abbreviation 'cis-' are terms used to describe people whose gender identity matches the sex that they were assigned at birth.
} 
by Saitō Yuki 斉藤由貴). During the course of the story, Fūma battles with his sexual desire for his best friend, all the while trying to hide his feelings from his wife and experiencing sexual encounters with other men. When he is finally able to disclose his sexual identity to his wife, she accepts it and the two continue their shared life. Discussions about sexuality are commonplace in the series, as are references to queer elements in Japan's history. However, while Fūma gets to spend a weekend with the object of his desire, the relationship is shown as unsustainable. For Claude Summers, Dōsōkai marked "a watershed in visibility" for sexual minorities in Japan (2004: 309). Wim Lunsing, on the other hand, interpreted the airing of Dōsōkai during prime time and on commercial television as a sign of a more tolerant attitude towards homosexuality in Japan, contrasting this to the situation in the United States (1997: 274). However, in my opinion, his comment should be read as a statement about attitudes in the US rather than an adequate interpretation of Dōsōkai's success. For Stephen Miller, the series provides "a personal statement that focused on desire, responsibility, and consequence" (2000: 107). The depiction of same-sex relationships - which only exist for a small timespan in the series and end before Dōsōkai's finale - is similar in almost all of the depictions of same-sex couples in the corpus of series I analysed.

Another element in the narrative of Dōsōkai that is also recurrent in TV series depicting same-sex desire between men is that the female main character has an intimate (though non-sexual) relationship with the gay male character. Mark McLelland observed the appearance of such pairings in Japanese movies such as Okoge おこげ (Fag Hag) and Kira kira hikaru きらきらひかる (Twinkle), as well as in Japanese TV series. He interpreted them as conservative concerning the depiction of homosexual desire:

In these dramas, gay men are not shown as separate from women's lives and concerns (as might be expected), but instead are constructed as women's best friends, ideal partners and allies in the battle to win increased space for female subjectivity. However, in co-opting gay men back into what are still seemingly heterosexual alliances, they are rather conservative (2000: 63, emphasis original).

Indeed, these observations seem to be true even for the 2015 TV series Gisô no füfu, which again depicts a marriage between a gay male character and a (seemingly) heterosexual female character. Other similarities between Dōsōkai and later series are the depictions of gay bars and/or references to Shinjuku Nichōme 新宿二丁目, a district in Tokyo widely known for the presence of gay bars. However, the series did not initiate a general trend towards an inclusion of queer or gay characters in TV series as some of the commentators mentioned above believed.

Of the relatively few TV series with queer male main characters, it is notable that three had scripts written by the same author: Yukawa Kazuhiko 遊川和彦. These dorama are the 2006 series Dare yori mo mama o aisu, the 2008 series Gakkō ja 
oshierarenai, and Gisō no füfu from 2015. Dare yori mo mama o aisu aired ten years after Dōsōkai. Here, the topic of queerness is notably less dramatised than in the earlier dorama. The series can be classified as a homu dorama ホームドラマ (a genre of TV series which focuses on the story of a family and its members), albeit one with unconventional gender roles. In this series, the husband Kamon Kazutoyo (Tamura Masakazu 田村正和) is portrayed as a stay-at-home dad whose wife Kamon Chiyo (Itō Ran 伊藤蘭) works as a lawyer. This setup alone is already exceptional for depicting a family situation that clearly differs from familial standards and norms in contemporary Japan. Akira (Tamayama Tetsuji 玉山鉄二), the family's eldest son, works as a hairdresser and his story is one of coming out, of self-recognition, and acceptance through his family. In the early episodes, Akira is seen as a young man unable to have long-term-relationships with women and unable to establish and preserve his personal boundaries. In the second episode of the series, the character Pinko (Abe Sadao 阿部サダフ) is introduced. Because Pinko's gender identity remains ambivalent, I will refer to the character with the gender-neutral pronouns "they/them²." Pinko is obviously and comically trying to win Akira as a partner and Akira's reluctance to disappoint them is shown as a character trait rather than an indicator of his sexual orientation. Pinko and Akira are two queer characters who are opposites in many ways and who deal differently with the awareness of their attraction towards one another. Pinko is more than once identified as okama オカマ by other characters, a term used by some members in Japanese queer communities but rejected by many because of its negative connotations. In Dare yori mo mama o aisu, some characters use this expression as a slur for effeminate homosexual men (e.g., Episode 3, 00:26:24), but in Pinko's case, the term also serves as a self-identification and as a marker for femininity. Asked in one of the later episodes whether Pinko is a man or a woman, Akira is unable to answer. In response to this overheard conversation, Pinko uses the term okama to describe their gender identity (Episode 10, 00:14:30). However, when Akira considers the possibility of a romantic/sexual relationship with Pinko, he wonders whether he himself is an okama as well. He also feels addressed by other characters' discussions of gay men. The series does not provide a conclusive answer to Akira's identity questioning process but ends with Akira and Pinko's wedding ceremony that Akira's family attends. This can be understood as a didactic call to accept the characters' queer and undefined identities and relationship.

The positive ending of the series Dare yori mo mama o aisu is as surprising as it is exceptional, but a self-identification with a queer category of sexual orientation also happens in later series. In Giso no füfu, it is the less stigmatised and more popular term gei that the main character proudly uses to present himself. Different again is the

\footnotetext{
${ }^{2}$ For further information about the pronoun and its usage, see: https://en.oxforddictionaries.com/definition/they.
} 
introduction of the main character in the series Gakko ja oshierarenai. The character Kazuki (Nakamura Aoi 中村蒼) is a young boy struggling with his romantic feelings for his male best friend Tomu (Morisaki Win 森崎ウィン), but is introduced as a character who had also been in love with a girl at an earlier point in his life. However, he does not use the term bisexual or any other term to describe his sexual orientation. Gakkō ja oshierarenai is a TV series not only featuring multiple queer characters but is told from the point of view of a queer character, including insights into his thoughts and dreams while following his story of coming out and the stories of his classmates. The dorama follows five seemingly heterosexual couples in a school setting, yet the male main character is unhappily in love with his male best friend. When he comes out to this friend and other characters in the series, he encounters understanding, and his friendly personality is quoted as one of the reasons why he does not experience rejection by the other characters despite his desire for another boy. The TV series adopts the most obviously didactic approach in my sample of series since the topic of homosexuality, but also other topics related to sexuality and youth, are discussed via the example of the students and their individual problems.

\section{Recent Examples of Series with Gay Characters}

One of the most recent TV series in my sample, Giso no füfu, recounts the story of the relationship between Kamon Hiro (Amami Yuki 天海祐希) and Himura Chōji (Sawamura Ikki 沢村一樹) - the series' main character, Hiro, is an unmarried misanthrope librarian who lives an isolated live. By chance she meets her former lover Chōji again, who works as a preschool teacher. Chōji explains to Hiro that after they split up several years ago, he had to come to terms with the fact that he is gay. However, he has been unable to explain this to his mother Himura Kanae (Fuji Sumiko 富司純 子), and having learned that she has cancer, he would now like to fulfil his filial duty and present a girlfriend to her. Hiro hesitantly agrees to pretend to be engaged and later even married to him. Their fake marriage ends when Hiro, who falls in love with Chōji, is emotionally unable to keep up the charade anymore. While their relationship is the focus of the narrative of Giso no füfu, both main characters also enter romantic same-sex relationships after ending the fake marriage. These relationships are then, in a second surprising turn, abandoned by the characters. The explanation given for this choice is that, despite being platonic, the relationship between the gay man and his female best friend is also an expression for their deep connection and is therefore as valid as a romantic and sexual relationship. The controversial ending of the series maintains a heteronormative order, highlighted by the second 'real' marriage of the main characters. At the same time, the series very obviously tries to promote the idea of the acceptance of individuality and diversity. In the case of the gay character, 
acceptance remains tied to his sexual abstinence, and his sexual desire is as much denied as the sexual desire of the woman marrying him.

In highlighting four dorama from the larger sample that feature main characters who can be read as gay, I show that there are different approaches present in the depiction of male same-sex desire. There is a common point between the last three that also applies to almost all depictions of same-sex desire between men in the other series I analysed: an absence of the depiction of sensuality and a desexualisation of the respective characters. Park Jin-Hyung also observes such an approach in other media and interprets this as a form of conditional normalisation:

In popular visual cultures like film, [norms] control the visibility of homosexual existence and desire. In this process, however, homosexuality also has to pay the high price of making invisible a key factor of its structure: eroticism (2008: 207).

This tendency also marks a contrast between the representation of gay men depicted in TV series on the one hand, and the depictions of same-sex romance in Boys Love productions on the other. Lastly, two rather recent series, Kasa o motanai aritachi wa and Otōto no otto 弟の夫 (My Brothers' Husband) deserve a special mention. Both series focus on straight characters who deal with homosexuality and internalised homophobia after gay people who were close to them die. The function of this specific narrative strategy might need further attention as it also serves to counter negative attitudes towards homosexuality without having to display actual romance between men. With few exceptions, the series depicting male same-sex desire didactically approach the topic of homosexuality with a heterosexual audience and their possible prejudices in mind, rather than aiming at providing validating representations of gayness.

\section{Eroticism, Sexualisation and Violence in the Depiction of Lesbian De- sire}

In the following sections, I analyse series focusing on female same-sex desire. The inclusion or exclusion of eroticism is a factor that plays out very differently in accordance to the gender of the portrayed characters. In contrast to series with male characters expressing same-sex desire, characters who can be read as female are regularly portrayed in a sexualised way and situations in which women are affectionate with one another are highlighted. In the earlier series of the 1990s, such images often include aspects of violence too. For example, two series aired in 1993 include scenes of implied sexual violence by women on women: Akuma no kisu and Hitorigurashi. Both stories are centred on the lives of single women in their late twenties in big cities. Akuma no kisu follows the story of Misao (Okuyama Yoshie 奥山佳恵), an aspiring 
illustrator for children's books, and two of her friends. It is a rather dark dorama and contains stories about rape, religious cults, sex work and drug abuse. Misao is depicted as a boyish and rather independent young woman. While struggling for success in her career as an illustrator, she is encouraged by her female boss Kitahara Rei (Kuroda Fukumi 黒田福美). However, it is soon shown that Rei is attracted to Misao, and the affection she shows toward her is not within the lines of a benevolent employer-employee relationship. In the setting of a hierarchically organised workplace, it is difficult for Misao to deal with the approaches of her boss. Rei is shown to be likely to abuse her position of power, and the dorama even includes a scene in which she develops plans to sexually assault Misao. Although she does not go through with her plan, her behaviour marks her desire as dangerous, near-uncontrollable, and misguided. In addition, another female employee of Rei is shown to have had a relationship with her in the past. This employee is jealous of Misao, scheming against her and interfering with her career. Thus, both female characters who have experienced sexual encounters with other women are shown as morally corrupt. Through the relationship with the other employee, it is made clear that Rei's desire for Misao is not directed towards a woman for the first time; it can therefore be interpreted as a marker of sexual orientation. This differs from the characters in Hitorigurashi, the next series I want to introduce as an example of a TV series mixing images of sexual violence with accounts of female-to-female intimacy.

Hitorigurashi follows the story of twenty-six year-old Miho (Tokiwa Takako 常 盤貴子) who is unhappy with her situation as an unmarried woman stuck in an unfulfilling job and pressured by her family to marry. She has a very close relationship with her best friend Kyōko (Nagasaku Hiromi 永作博美) whom she has known since childhood. From the outset of the series, the closeness of the two characters is accentuated. They spend most of their time together and are often shown in scenes of physical intimacy such as while sharing food or hiding together naked under a blanket after a water pipe burst. They also verbally express their affection for one another, and when she moves into her own apartment, Miho immediately passes her spare key to Kyōko to use in case of emergency. In their talks about romantic relationships, the characters are made out to be predominantly attracted to men (other options are in fact not mentioned), although Miho is at first shown to be too timid to enter a romantic relationship. Kyōko meanwhile has multiple sexual and romantic relations with men, during which she is repeatedly disappointed. The women also jokingly talk about the likelihood of dating each other if one of them were a man in the TV show's first episode. Clearly, there is a significant difference between the professional relationship between Rei and Misao in Akuma no Kisu and the private relationship between Kyōko and Miho in Hitorigurashi. More importantly, in Hitorigurashi, affection between the main characters is shown to be mutual at first. However, this changes when Miho starts dating a man and Kyōko, who had encouraged their meeting at first, is overcome 
by jealousy. As events unroll, Kyōko's feelings for Miho intensify, and she lastly even considers sexually assaulting her unconscious best friend before abandoning the idea.

In both Akuma no kisu and Hitorigurashi, frustration and violent behaviour are the results of rejection and are not necessarily caused by - yet are somehow tied to sexual orientation or desire for a person of the same sex. This mode of representation makes queer characters appear villainous, deceitful and immoral. Such representations prompted prominent lesbian blogger Gōtō Keiko to call the 1990s "the 'Era of Dark and Gloomy Lesbian Drama"' (2008). To my knowledge, similar images of gay men are rare. Sugiura Ikuko 杉浦郁子 identified a stereotype about female same-sex desire prevalent in mainstream magazines of the 1970s that depicted lesbian women. She described it as the "Carnal Lesbian Motif" (Sugiura 2007: 131) and, according to her, it is still prevalent in imagined lesbian desire in Japan. In my opinion, the TV series under discussion can be interpreted as relying on such a stereotype. Though the stereotype is not as present anymore in recent examples of TV series depicting lesbian desire, it still serves as a trope that differentiates both homosexual from heterosexual desire and lesbian from gay desire. This can be seen in the example of the series Gakkō ja oshierarenai in which the affections of the side-character for another female character are rejected. This character also reacts with anger and frustration, just like Kyōko in Hitorigurashi and Rei in Akuma no kisu, and jealously schemes against the desired girl's interactions with other characters. This character's immorality is shown by her near-acceptance of the desired girl's affection as a payment for a favour she is able to grant as the president of the student council. Unlike the bisexual male character in the same series, this female student is also shown to reject men categorically, including the possibility of intimacy with men. Her sexual orientation is never mentioned but rather has to be deduced from her behaviour towards female characters and statements about men.

\section{Lesbian Desire and Gender Confusions}

In the following section, I explore in somewhat more detail a number of dorama that question gender identities while also portraying desires that can be read as lesbian. Horie Yuri 堀江有里 states that there are two persisting views on lesbians in Japanese society: one draws a connection with lesbian pornography, whereas the other views lesbians as "masculinised" (2006: 81). In some of the earlier examples of TV series presented above, especially those featuring non-consensual but eroticised scenes, echoes of this understanding of sexuality in the context of pornography can be found. Horie's criticism of the "masculinisation" of lesbian women is somewhat more difficult to treat and understand. The scholar herself explains that in the history of the construction of lesbian identities, relationships between women tended to mirror 
heteronormative relationships in their distribution of gender roles due to a lack of other examples (Horie 2010: 72). Yet in the 1970s, the classification of lesbians into categories such as butch/femme or tachi タチ/neko ネコ were criticised within Japanese queer communities (Maree 2015: 232). Given that there is a broad spectrum of gender performances and identities that are not necessarily connected to sexuality, representations of "feminine men" and "masculine women" who may be heterosexual or homosexual should be welcome additions to heteronormative representations on television. Nevertheless, the confusion of gender identity and sexual orientation needs to be further interrogated. In this regard, the series 29-sai no yūutsu paradaisu sāti and Rasuto furenzu can be said to be contrasting examples in their depiction of gender and sexuality as categories which can be transgressed.

In contrast to the examples of lesbian desire mentioned above, which show intimacy between women and female same-sex desire in a negative light, the TV series 29-sai no yūutsu paradaisu sātī features a very likeable queer female character. The series is based on a novel by famous crime and suspense author Nonami Asa 乃南ア サ. The story follows twenty-nine year old Yuriko (Ishida Hikari 石田ひかり) who meets her former best friend Natsumi (Shimizu Misa 清水美沙) again after a period of eleven years. The two characters pick up their friendship and start living together after Natsumi conveys to Yuriko that she is a lesbian. Yuriko's first reaction to the revelation of Natsumi's sexuality is that of shock. She then starts reading up on lesbianism, informing herself by looking through Natsumi's books on the subject, reading aloud, and voicing her thoughts, thereby inviting viewers to gather information gradually about the importance of recognising Natsumi's sexuality.

Negative experiences are not excluded from this narrative: since coming out, Natsumi is no longer in contact with her parents but received a flat from them under the condition of cutting off contact; her parents now treat her as a stranger (tanin 他 人). Despite obviously being a source of pain for Natsumi, she tries to make light of these circumstances. Her social surrounding in the series consists of people who know her and from whom she has nothing to hide. When they were at school together, Natsumi fell in love with Yuriko and this unrequited desire on her part forms part of the narrative of the series. However, Natsumi finds that in time her feelings for Yuriko change, and she values their friendship, regarding Yuriko more as a younger sister by the end of the series. Yet there is another woman in the series with whom she forms a romantic relationship. The wife of a violent gang member (yakuza ヤクザ) approaches Natsumi and they start an affair. Unfortunately, this relationship does not last, and the yakuza wife finally returns to her husband, telling Natsumi rather cruelly that she would never be able to understand the bond between a man and a woman.

In 29-sai no yūutsu paradaisu sātī, Natsumi expressly identifies as a lesbian, and she uses her androgynous appearance as a signifier of her sexuality. In the first episode, she asks the unsuspecting Yuriko whether she does not see or recognise from her 
appearance and her demeanour that she is a lesbian. At this point, she does not (yet) use the term rezubian to refer to herself, but rather is identified by a third person (a man) as onabe オナベ and agrees with the identification. Similar to okama, onabe is also used derogatively to describe either women who desire women or "masculine women." This term, though sometimes translated as lesbian, was at first used to describe cross-dressing women and therefore includes a gendered notion (Maree 2015: 231). Later on in the first episode, Yuriko - who has not yet moved in with Natsumi - visits her and finds a pair of men's undergarments in Natsumi's apartment, prompting her to assume that there must be a man in Natsumi's life after all. However, Natsumi responds that the pants belong to her and she is indeed wearing very similar pants now, jokingly offering to show them to Yuriko. Natsumi's reaction, turning a statement in which her appearance is questioned around to make fun of the person asking, is a strategy the series also applies in other scenes/episodes. More than once, characters who are unaccepting of Natsumi's demeanour are either ridiculed or shown as misguided in their perception. An example for such a situation is the visit of Yuriko's mother and future sister-in-law to the flat. So as not to shock them, Yuriko persuades Natsumi to change her dress into a more feminine one; she also alters her speech while talking to Yuriko's relatives. However, she is unable to keep up the disguise and ends up sending the visitors into a frenzy when she sits back open-legged in her skirt and lights a cigarette.

Queer friends of Natsumi seem to share her preference for an androgynous appearance. When Yuriko first meets some of Natsumi's friends, she is confused about their genders and shocked when someone she assumed to be a man is introduced to her as a woman. However, the women Natsumi expresses desire for and who respond to her desire usually come off as very feminine, with longer hair, dresses, make-up etc. Her ex-girlfriend Mari - with whom she used to live - can be understood as the epitome of a feminine lesbian character. This division of gendered appearances can be interpreted in line with the stereotypical tachi-neko distribution of gender roles in the common representation of lesbian relationships in Japan.

In the series discussed so far, same-sex desire was made visible, sexual orientation was sometimes implied but never characterised, and was usually represented in a negative light. In contrast, 29-sai no yüutsu paradaisu sātī includes what Mauro Neves (1998) interprets as a positive representation of a lesbian character. The series is exceptional in the way it directly addresses the main character's sexual orientation and identity and in showing her to be part of a community with other friends who can be identified as queer. When Gōtō Keiko (2008) classified the series as one in which an "onabe" character can be found, she may have meant a specific representation of lesbians for whom a masculine appearance forms part of their identity.

In contrast to 29-sai no yūutsu paradaisu sātī, Rasuto furenzu is a story in which one of the protagonists is constructed by the scriptwriters as a character who can be 
interpreted either as a male trans-character or a cis-gender lesbian character (Keiser 2008). In line with the more common reading of the dorama as lesbian, I will refer to the character with female pronouns. The story of Rasuto furenzu follows young hairdresser Aida Michiko (Nagasawa Masami 長澤まさみ) and her relationship with Oikawa Sōsuke (Nishikido Ryo 錦戸亮), her increasingly violent boyfriend. Domestic violence can thus be said to be the main topic of the series. Michiko is helped by Kishimoto Ruka (Ueno Juri 上野樹里), a friend from her school days who is - unbeknownst to Michiko - in love with her. Ruka is shown as a character who is uncomfortable with the female gender ascribed to her; at some point, she considers sex reassignment surgery but does not go through with this plan. Instead, the character comes out to her father in the series' last episode as someone who likes women, and this fact is accepted by the father. Given there is no further mention of the character's rejection of the female gender, the coming out can be read as a lesbian coming out rather than a coming out as a trans-man. Yuen Shu Min attributes the "potential to queer conventionally constructed notions of gender and sexuality" to this television drama (2011: 384). Yuen interprets Rasuto furenzu's main character Ruka as a trans-character and compares it to earlier series that "tend to construct and perpetuate a discourse of transgenderism that is largely based on the medical model" (ibid.). Indeed, scriptwriter Asano Taeko 浅野妙子 points out in an interview with the blogger Yuki Keiser 雪カイザー that the character was intended to be a trans-character only for lack of a better word to describe the character's identity. Furthermore, the scriptwriter deliberately did not construct the character according to the suggestions of the trans-men she consulted. They would have preferred clear gendered markers such as the use of the masculine ore 俺 instead of the more feminine watashi 私 in their self-referential language (Keiser 2008). Yuki Keiser confirmed that the dorama had a huge impact on lesbian communities despite the main character not being clearly identifiable as female (ibid.). One must also take into consideration that the viewers' interpretation can go beyond the intentions of the series' producers, and the choice for a female cisgender actress for the role makes an interpretation of the character as female more likely. Such an interpretation would allow one to see a continuance of what Horie described as a masculinisation of the 'lesbian trope' (as previously mentioned).

\section{Recent Depictions of Lesbian Desire}

The most recent example of the representation of female same-sex desire I want to introduce is the series mentioned in the introduction to this article: Toranjitto gāruzu. This series' format differs from most of the other series discussed because each episode is only about twenty minutes long. As is made clear by the advertisement, the narrative of the series concentrates on two girls and their love story. The producers of the low-budget series with hitherto unknown actors were also the producers of Japan's 
highly popular reality TV show called Terrace House テラスハウス. This was the second reason, besides its content, for the series to be heavily advertised.

The two main characters in Toranjitto gāruzu meet when Sayuri's father and Yui's mother declare their plan to marry each other, move in together, and form a family. Shortly before their first meeting, Yui - an aspiring photographer - had already taken notice of Sayuri and photographed her while she was praying at a Shintō shrine. It is also Yui who approaches Sayuri, first kisses her and declares her un-sisterly affection for her. In the course of the narrative, Sayuri is actively processing her emerging feelings for Yui - she questions what they mean with regards to her sexual identity, but also with regard to the family situation in which both young women find themselves placed. When the two characters enter a relationship, the family situation prompts them to break up. The series thus offers combinations of possible taboos in the depiction of the main characters' romantic relationship. Therefore, the obstacle to the relationship cannot be identified as a general opposition to same-sex desire or homophobia. Yui, who asks the parents about their opposition to the relationship, points out this aspect (Episode 7, 00:01:49-00:01:53). The question is unanswered but the earnestness with which the characters pursue their relationship ultimately convinces the parents to accept it. In the last episode of the series, the two main characters appear as a couple, and they can - after receiving familial support - publicly display their affection. The producers and actresses clearly aimed at providing a normalised depiction of a lesbian relationship (Modellpress 2015), but I suggest this attempt was only partly successful. Furthermore, it must be mentioned that the series also relies on the sexualised image of young women, a factor that the LGBT activist Muraki Maki 村木真 紀 criticised as "outdated" (McKirdy 2015).

Another sympathetic representation of a self-identified lesbian character can also be found in the already discussed 2015 dorama Gisō no füfu. Like Gakkō ja oshierarenai, this TV series also features a queer male main character, a man whose sexual desire is only directed towards men, but who is platonically in love with his female best friend (and later wife). The lesbian character in Giso no füfu is a divorced single mother who experienced physical abuse in her previous relationship and is therefore only able to love women. Though her character is shown to be caring and friendly, the fact that an explanation - the trauma of abuse - is given for her sexual orientation brings back memories of pathologising views on same-sex sexual orientation. Interestingly there is no such explanation needed for the male main character's sexual orientation. 


\section{The Significance of Coming Out Processes and Situations for Queer Characters}

The latter part of this article highlights narrative tropes applied in both the depiction of non-normative gender-performances and non-normative desire of characters of different genders, and points out shortcomings in queer characters' narrations. Many of the TV series with queer main characters show how they experience an internal conflict regarding their desire for someone of the same sex and/or gender. Often, this conflict takes the form of questioning one's sexuality, and these mental processes result in an acceptance of being in some way different from other characters and societal norms, especially in the most recent series. This acceptance does not necessarily take the form of an identification with a specific category of gender or sexual orientation. Regardless of whether the character finally receives acceptance as an individual or as someone who identifies with a non-normative sexual orientation, the internal conflict the character experiences is usually described as painful.

Additionally, many of the series include scenes in which a queer character confesses a desire for another character of the same sex and/or gender to friends, family, or the desired person. This narrative strategy can be identified as the retelling of internal and external coming out processes and situations. The internal coming out process is focused on in the case of Ruka in Rasuto furenzu, Jun ichirō in Asunaro hakusho, and Akira in Dare yori mo mama o aisu. It is followed by a confrontation with people close to the character (such as family members or friends) in the series Sono toki hāto wa nusumareta, Gakkō ja oshierarenai, and in the case of both main characters in Toranjitto gāruzu. Only the characters Natsumi in 29-sai no yūutsu paradaisu sātī, Pinko in Dare yori mo mama o aisu, and Chōji in Gisō no füfu do not go through such a process but rather are conscientious of their sexual orientation/gender identity from the beginning of the series. Chōji's case is exceptional because he is a character who, despite proudly claiming a gay identity, makes an unsuccessful attempt to change his sexual orientation. Coming out is not always voluntary either: the characters Natsumi, Pinko and Chōji all experience situational pressure to 'confess' their sexual orientation to friends, family members or, in Chōji's case, to work colleagues. The repetition of the act of coming out can be interpreted as a marker of difference between heterosexual and homosexual desire, which prevents the normalisation of the depiction of queer desire. To emphasise the function of coming out as a marker of difference between same-sex and heteronormative desire, the series often dramatise the point of confession. The queer characters are usually unable to predict the other characters' reaction and fear rejection. Obviously, the straight characters never share the experience of having to deal with their desires or of having to probe the reaction of friends, family, or peers when they talk about their desires.

According to Tomoe Kentarō (2014: 12), sexual minorities in Japan experience 
higher rates of psychological health problems relative to people who identify as heterosexual. The scholar links the repetitive visualised performance of coming out to psychological pressure which might be experienced by people who understand this narrative strategy as a differentiation between homosexuality and heterosexuality. It is also possible to understand the coming out performances in the TV series as educational scenes for heterosexual viewers who are presented with a template for correct behaviour in case a non-heterosexual friend or family member comes out. Yet even if such didactic effects were in the interest of the series' producers, the impact of the representation on viewers who might identify with the struggles of queer characters must also be considered. The latter are denied a normalised, non-sensationalised representation of queerness.

\section{Political Aspects of Queerness}

While a differentiation between same-sex and opposite-sex desire is reinforced through the accentuation of coming out processes, many aspects of the lives of queer people do not receive much attention in the TV series. By emphasising psychological processes and personal experience, a depolitisation of queerness also takes place. On the one hand, showing a lone queer character in a setting where most other characters are seemingly straight fosters the idea of the exceptionalism of queer desire. At this point, it is important to note that references to queer communities in Japanese TV series are not the standard, but they do appear. As already mentioned, 29-sai no yüutsu paradaisu sāt $\bar{\imath}$ shows the character Natsumi with a circle of non-gender-conforming and/or lesbian friends. Other examples where the presence of queer communities or places are addressed are Dōsōkai, Dare yori mo mama o aisu, or Gisō no füfu, which all feature places introduced as designated spaces for people who identify as queer. However, they are usually visited by gay people or drag queens; female characters who could be read as lesbians are seldom present. The only place shown as a community space for homosexual people of different genders is in the online series $R a b u$ Kore Tōkyō. In this series, a bar called $U B U$ is introduced as an important place where the queer characters meet friends and potential partners on a regular basis. Just like the other queer places in the aforementioned series, however, it is shown through a heterosexual and sensationalised gaze.

In recent years in Japan, political aspects of queerness have received increased awareness. As mentioned in the introductory section of this article, not only visibility plays a role in the discussions of LGBTIQ (lesbian, gay, bisexual, transgender/transsexual, intersex and queer/questioning) issues in the media; there are also concrete demands directed towards the state and wider society. For example, a possible change to marriage laws, which currently only allow for the marriage of opposite-sex partners, 
was discussed in various media. The idea of a legal change to allow same-sex partners to marry is also under controversial discussion by queer scholars and members of LGBTIAQ (lesbian, gay, bisexual, transgender, intersex, asexual, queer and other sexual orientations) communities (see Taniguchi 2015; Tamagawa 2016). Since the 1990s, there have been attempts by different groups to enhance protections against discrimination, often by emphasising belonging to sexual minority groups and therefore being a tōjisha 当事者 (a person concerned). Furthermore, the organisation of pride parades and other public events by non-governmental organisations or groups consisting of members of queer communities, which formulate demands to be recognised as equal citizens, has been an ongoing process. With concentration on the private experiences of individual queer characters and the omission of any mention of such political activism, the TV series depoliticise the perception of queerness in the Japanese public realm.

\section{The Trope of Unrequited Love}

Another common factor in most series - regardless of the queer character's specific gender identity - is that both same-sex desire and intimacy happen only momentarily, but cannot develop into a long-lasting/stable relationship. Same-sex romance is often placed in a narrative of one-sidedness and lack of fulfilment. This is the case in the series Hitorigurashi, Akuma no kisu, Asunaro hakusho, Rasuto furenzu, and Gakkō ja oshierarenai where the queer characters express one-sided romantic emotions for a straight character. The one-sidedness of attraction provides for a setting in which scenes showing intimacy between women as well as sexual and romantic images such as kissing can be provided; the affections are depicted, however, as non-consensual, as in the cases of Hitorigurashi and Akuma no kisu. The degree to which lines of consent are crossed falls in line with the characterisation of people who express samesex desire as immoral or as sad and pitiable characters.

On the other hand, in Sono toki hāto wa nusumareta, Dōsōkai, 29-sai no yūutsu paradaisu sātī, Rabu konpurekkusu and Gisō no füfu, the formation of same-sex couples is based on mutual attraction and they separate again after short periods of time. Exceptions to this narrative trope are found solely in the series Dare yori mo mama o aisu and Toranjitto gāruzu. However, is this trope also one that differentiates samesex from heterosexual desire and intimacy? Is the discrepancy of the depiction of queer characters and the impossibility of living out queer desire specific to depictions of homosexuality in Japanese TV series? To answer these questions, one needs to consider whether heterosexual relationships are ordinarily allowed to develop or whether they also encounter obstacles in Japanese TV series.

Unrequited love is a very popular theme in TV series and, according to producer Ōta Tōru 大多亮, is one of the main motifs of the so-called "post trendy drama" of 
the 1990s. He sees this trope as a well-received feature for female audiences who identify with usually female main characters' emotions:

In terms of narrative, what mostly appeals to the young female audience in general is unrequited love. Of course, I am talking about women's unrequited love. It is absolutely ineffective the other way around because men's unrequited love is nothing spectacular or appealing (Ōta 2004: 73).

The topic of unrequited love is, according to Ōta, only appealing because it allows the viewer to sympathise with the rejected character. In his view, the female and supposedly heterosexual viewer would be unable to identify with the suffering of a straight male character. However, given that most series depicting gay men also target a mainly female audience, one can deduce that this audience is expected to have a stronger ability to connect with gay male characters by the producers of the series. To understand whether the narrative trope of unrequited love differentiates between the different forms of desire, I cross-examined the series in my corpus for their treatment of romance in opposite-sex partners. The only example of a series in which a differentiation is very obviously made is Gakkō ja oshierarenai, in which almost all heterosexual characters are part of a romantic relationship by the end of the series, while the queer characters are not.

In contrast to Gakkōja oshierarenai, in most of the series from my sample, heterosexual female main characters remain single just like their queer friends. The thesis of unrequited love as a specifically queer topic thus does not apply to my sample of series and should therefore be refuted. However, it must be stated that while the trope of unrequited love may generally be strong in Japanese TV series, the spectrum of representations for opposite-sex desire is still much broader than the spectrum of representations for queer desire and includes many narrations with 'happy endings.' It therefore remains significant that there are so few positive examples of loving and accepted relationships between same-sex partners.

\section{Concluding Remarks: Changes over the Course of Twenty-Five Years}

The representation of queer characters in TV series can contribute to the visibility of queerness, but surprisingly the number of TV series depicting sexual minorities does not seem to have risen in accordance with the increased visibility of LGBT-identifying people in other areas of Japanese society. On a scholarly and activist level, the years after the so-called "gay boom" produced a considerable number of events such as rainbow prides, movie festivals and research platforms such as the foundation of the currently-disbanded JAQS (Japan Association for Queer Studies). Moreover, an increasing number of studies addressed the life (and work) situations of LGBTIAQ 
individuals (e.g., Taniguchi 2015; Mitsunari 2015; Otsuka and Kido 2017; Yanagisawa et al 2017). Not only were these developments not addressed in TV series, but the number of TV series with a focus on same-sex desire also remains relatively small, thus increasing the burden on the few exceptions taken as representative for the depiction of same-sex desire. As Suganuma points out, "given the rich existence of queer culture in society, one cannot describe Japanese queer culture as 'invisible'. However, this does not denote that hetero-normative society has been tolerant of postwar queer culture" (2007: 490). In this article, I showed that, while contributing to visibility, the depiction of queer characters in TV series sometimes reproduces stereotypes and images that risk naturalising perceived differences between minorities and majority groups.

In the 1990s and 2000s, only a handful of other series included gay or lesbian characters who were most often side characters. Of the series with gay side characters, the series Nodame Cantabile, BOSS and Rasuto Shinderera are outstanding examples of stereotypical representations of gayness insofar as the male characters are shown as effeminate in the way they dress, speak, or use body language. In Nodame Cantabile, in addition to his feminised language and gestures, the supposedly gay character who is unhappily in love with the straight main character also wears an Afro hairstyle. The combination of racial and gendered elements serves to create a comical and laughable character. Such stereotypes can be read as elements ascribed to minority characters that serve to stabilise existing gendered power structures, but while they are also present in some of the series with gay main characters, in the latter example they are not the protagonist's defining characteristic.

A notable difference between the images of queerness found in the 1990s, 2000s, and thereafter is the degree to which the narratives around homosexuality are dramatised. There appears to be a decrease in the depictions of stories that connect tragic and violent aspects to queer lives. In Dōsōkai, violence is omnipresent, and one of the main characters is ultimately murdered by the end of the series. Under less dramatic circumstances, the gay side character in the 1996 series Asunaro Hakusho also dies tragically in a car accident. The depiction of non-consensual intimacy in the earlier representations of queer female characters should also be understood as a violent trope. As I tried to show, this trope has been taken up not in the form of sexual but as psychological violence, even in more recent dorama; this includes those that feature a positive portrayal of queerness, such as the 2007 series Gakkō ja oshierarenai. However, in the broader view, the more recent series tend to exclude scenes of violence and this can be considered as a positive development.

The differentiation between homosexuality and heterosexuality - and the naturalisation of such a difference - is obvious when the former is associated with misplaced desire, unrequited love, and confusion about one's own gender identity. In this article, I paid special attention to characters whose gender performance was explicitly non- 
conforming with regard to binary categories of gender. As I tried to show, it would be short-sighted to read these gender-ambivalent characters as signs of tolerance towards gender-fluidity in Japan; rather, they are sometimes a sign of confusion of sexual orientation and gender identity, especially in the case of the depiction of 'masculinised' women. These depictions also follow patterns where gender ambivalence is applied either comically or tragically to differentiate the queer characters from their heterosexual cisgender counterparts. It can thus be stated that in the sample of TV series analysed, a differentiation not only between homosexual and heterosexual desire, but also between normative gender-performances and non-normative gender-performances, can be found.

Additionally, the ways in which empathy with queer characters is invoked needs to be critically interrogated too. In 2013, LGBT activists Makimura Asako 牧村朝子 and Munakata Miki 宗方美樹 criticised that the image of LGBT characters in Japanese television consists mainly of drag queens in comedic, laughable appearances and of narratives about transgender people supposed to "make the viewer cry" (Yamamoto 2013). Through the examples discussed in this article, however, I tried to show that characters with non-normative gender identities as well as non-normative sexual orientations are often portrayed as experiencing their difference as a burden. This narrative strategy is dealt with by the depiction of internal conflicts and through sometimes dramatised external coming out situations. Didactic moments in the series are very obviously applied to promote ideas of individuality and diversity. Moments in which homosexuality is made a story line or in which characters 'come out' as being in love with a character of the same sex and/or gender can create empathy. However, counter to such attempts by the producers - especially of recent series - stand the traps of misrepresentation and the continuous sensationalising, heterosexual gaze, which poses a challenge for future productions to avoid.

\section{REFERENCES}

Dobbins, Jeffrey. 2000. "Becoming Imaginable: Japanese Gay Male Identity as Mediated through Popular Culture.” Master thesis, McGill University, Canada.

Freedman, Alisa and Kristina Iwata-Weickgenannt. 2012. “'Count What You Have Now. Don't Count What You Don't Have': The Japanese Television Drama Around 40 and the Politics of Women's Happiness.” Asian Studies Review, 35 (3), pp. 295-313.

Görlach, Fauve. 2011. “'Unter der Maske der Liebe'. Häusliche Gewalt in Last Friends.” In Michiko Mae and Elisabeth Scherer, eds., Japan-Pop-Revolution: Neue Trends der japanischen Gesellschaft reflektiert in der Popkultur. Düsseldorf: Düsseldorf University Press, pp. 123143.

Gössmann, Hilaria. 1997. "Neue Rollenmuster für Frau und Mann? Kontinuität und Wandel der Familie in den japanischen Fernsehdramen der Gegenwart.” In Michiko Mae and Ilse Lenz, eds., Getrennte Welten, gemeinsame Moderne? Geschlechterverhältnisse in Japan. Opladen: Leske and Budrich, pp. 96-122. 
Gössmann, Hilaria. 2016. "Kontinuität und Wandel weiblicher und männlicher Lebensentwürfe in japanischen Fernsehserien (terebi dorama) seit der Jahrtausendwende.” In Michiko Mae, Elisabeth Scherer and Katharina Hülsmann, eds., Japanische Populärkultur und Gender. Wiesbaden: Springer, pp. 127-148.

Gōtō, Keiko. 2008. "Nihon no L dorama jijō 日本の L ドラマ事情 [Situation of L-Drama in Japan].” Online: http://www.tokyowrestling.com/articles/2008/03/japanese_1_drama_1.html (accessed: March 25, 2017).

Kanemoto, Emi and Kristie Collins. 2017. “'It's a Wonderful Single Life': Constructions and Representations of Female Singleness in Japan's Contemporary Josei Dorama.” In Toyosaki Satoshi and Eguchi Shinsuke, eds., Intercultural Communication in Japan: Theorizing Homogenizing Discourse. Oxon: Routledge, pp.41-54.

Keiser, Yuki カイザ雪. 2008. “'Rasuto furenzu’ no kyakuhonka Asano Taeko-san no intabyū 『ラ スト・フレンズ』の脚本家・浅野妙子さんのインタビュー [Interview with the Screenwriter of Rasuto furenzu, Taeko Asano].” Online: http://www.tokyowrestling.com/articles_eg/2008/07/last_friends_1.html (accessed: May 14, 2017).

Khor, Diana. 2005. "The Foreign Gaze? A Critical Look at Claims about Same-Sex Sexuality in Japan in the English Language Literature." Gender and Sexuality, 6, pp. 45-60.

Maree, Claire. 2013. "Writing Onê: Deviant Orthography and Heternormativity in Contemporary Japanese Lifestyle Culture.” Media International Australia, 147, pp. 98-110.

Maree, Claire. 2015. “Queer Women's Culture and History in Japan.” In Mark McLelland and Vera Mackie, eds., Routledge Handbook of Sexuality Studies in East Asia. Oxon: Routledge, pp. 230-243.

Maser, Verena. 2015. "Beautiful and Innocent: Female Same-Sex Intimacy in the Japanese Yuri Genre.” Ph.D. thesis, University of Trier, Germany.

McCormick, Joseph. 2015. “Japan's First Ever Lesbian Drama Accused of Being 'Out-Of-Date'.” Online: http://www.pinknews.co.uk/2015/10/23/japans-first-ever-lesbian-drama-accused-ofbeing-out-of-date/ (accessed: March 3, 2018).

McKirdy, Andrew. 2015. "Fuji TV Announces Japan-First Lesbian Drama, but Attracts Criticism for 'Outdated' Portrayal:” Japan Times, October 22, 2015; online: http://www.japantimes.co.jp/news/2015/10/22/national/social-issues/fuji-tv- announces-japan-first-lesbiandrama-heels-advances-lgbt rights/\#.WV4bio5pw1g (accessed: March 20, 2018).

McLelland, Mark. 2015. Boys Love Manga and Beyond. Jackson: University Press of Mississippi.

McLelland, Mark and Vera Mackie. 2015. Routledge Handbook of Sexuality Studies in East Asia. Oxon: Routledge.

Mesquita, Sushila. 2008. "Heteronormativität und Sichtbarkeit.” In Rainer Bartel, Ilona Horwath, Waltraud Kannonier-Finster, Maria Mesner, Erik Pfefferkorn, and Meinrad Ziegler, eds., Heteronormativität und Homosexualität. Innsbruck: Studienverlag, pp. 129-148.

Mikos, Lothar. 2008. Film- und Fernsehanalyse. Konstanz: UVK Verlagsgesellschaft.

Miller, Stephen. 2000. "The (Temporary?) Queering of Japanese TV.” Journal of Homosexuality, 39 (3), pp. 83-109.

Mithani Forum. 2014. "New Heroines for a New Era? Single Mothers in Contemporary Japanese Television Drama." Acta Asiativa Varsoviensia, 27, pp. 1-19.

Mitsuhashi, Junko. 2006. "The Transgender World in Contemporary Japan: The Male to Female Cross-Dressers' Community in Shinjuku.” Translated by Hasegawa Kazumi. Inter-Asia Cultural Studies, 7 (2), pp. 202-227.

Mitsuhashi, Junko 三橋順子. 2009. “Terebi no naka no seiteki mainoritīテレビの中の性的マイノ リティー [Sexual Minorities in Television].” Kinyōbi 金曜日 [Friday], 17 (22), pp. 22-23. 
Mitsuhashi, Junko 三橋順子. 2016. "Nihon ni okeru rezubian no inpei to sono eikyō 日本におけ るレズビアンの隠蔽とその影響 [The Concealment of Lesbians in Japan and Its Influences].” Seishakai/bunkashi kenkyūsha Mitsuhashi Junko no ākaibu. 性社会・文化史研究者 三橋順子 のアーカイブ [Archive of Gender Studies and Cultural Studies Scholar Mitsuhashi Junko]. Online: http://zoku-tasogare-2.blog.so-net.ne.jp/2016-08-11 (accessed: May 14, 2017).

Mitsunari, Miho 三成美保. 2015. Dōseiai o meguru rekishi to hō: Songen toshite no sekushuariti. Shohan. 同性愛をめぐる歴史と法 : 尊㛜としてのセクシュアリティ [History and Law of SameSex Love, the Sexuality of Respect]. Tōkyō 東京: Akashi Shoten 明石書店.

Neves, Mauro. 1998. "Reflecting Society, TV Dramas in Japan and Brazil.” Thesis paper, Centre for Iberian and Latin American Studies, University of California San Diego, United States.

News Team. 2015. "Fuji TV Announces First Lesbian Drama for Japan.” Pridelife, October 22, 2015; online: https://pridelife.com/fuji-tv-announces-first-lesbian-drama-for-japan/ (accessed: June 22, 2019).

Nishino, Kenji-Thomas. 2016. "Genderbending - Grenzgänge in Mainstream-Anime und Manga.” In Mae Michiko, Elisabeth Scherer and Katharina Hülsmann eds., Japanische Populärkultur und Gender. Wiesbaden: Springer Fachmedien, pp. 97-126.

Ōta, Tōru. 2004. "Producing (Post-)Trendy Japanese TV Dramas.” In Iwabuchi Koichi, ed., Feeling Asian Modernities: Transnational Consumption of Japanese TV Dramas. Hong Kong: Hong Kong University Press, pp. 69-86.

Ōtsuka, Takashi 大塚隆史 and Kido Kentarō 城戸健太郎. 2017. LGBT no hiroba LGBT のひろ ば [The Space of LGBT]. Tōkyō 東京: Nihon Hyōronsha 日本評論社.

Park, Jin-Hyung. 2008. "Representation, Politics, Ethics: Rethinking Homosexuality in Contemporary Korean Cinema and Discourses." In Fran Martin, Peter Jackson, Mark McLelland, and Audrey Yue, eds., AsiaPacifiQueer: Rethinking Genders and Sexualities. Urbana, IL: University of Illinois Press, pp. 197-216.

Rückert, Jasmin. 2017. “Transit Girls.” In Barbara Metzler, Andreas Riedl, Diotima Bertel, Julia Himmelsbach, and Lara Möller, eds., Von der Reflexion zur Dekonstruktion? Kategorien, Typen und Stereotype als Gegenstand junger Forschung. Wien: danzig \& unfried.

Saitō, Shinichi. 2007. "Television and the Cultivation of Gender-Role Attitudes in Japan: Does Television Contribute to the Maintenance of the Status Quo?" Journal of Communication, 57, pp. 511-531.

Schaffer, Johanna. 2008. Ambivalenzen der Sichtbarkeit. Über die Visuellen Strukturen der Anerkennung. Bielefeld: transcript.

Scherer, Elisabeth. 2016. "Alternative Lebensmodelle von der Stange? Konstruktion und Rezeption von Geschlechteridentität in japanischen Fernsehserien (terebi dorama)." In Mae Michiko, Elisabeth Scherer, and Katharina Hülsmann, eds., Japanische Populärkultur und Gender. Wiesbaden: Springer Fachmedien, pp. 149-175.

Shimizu, Akiko. 2007. "Scandalous Equivocation: A Note on the Politics of Queer Self-Naming:" Inter-Asia Cultural Studies, 8 (4), pp. 503-516.

Suganuma, Katsuhiko. 2006. "Enduring Voices: Fushimi Noriaki and Kakefuda Hiroko's Continuing Relevance to Japanese Lesbian and Gay Studies and Activism.” Intersections, 14. Online: http://intersections.anu.edu.au/issue14/suganuma.htm (accessed: May 14, 2017).

Suganuma, Katsuhiko. 2007. "Associative Identity Politics: Unmasking the Multilayered Formation of Queer Male Selves in 1990s Japan.” Inter-Asia Cultural Studies, 8 (4), pp. 485-502.

Sugiura, Ikuko. 2006. "Lesbian Discourses in Mainstream Magazines of Post-War Japan: Is Onabe Distinct from Rezubian?” Journal of Lesbian Studies; 10 (3/4), pp. 127-144.

Tamagawa, Masami. 2016. "Same-Sex Marriage in Japan.” Journal of GLBT Family Studies, 12 (2), pp. 160-187. 
Taniguchi, Hiroyuki 谷口洋幸. 2015. “Dōseikon wa kokka no gimu ka「同性婚」は国家の義務か [Is Same-Sex Marriage the State's Responsibility?]” In LGBT - Nihon to sekai no riaru gendai shisō LGBT - 日本と世界のリアル-現代思想 [LGBT - The Real Japan and World in Contemporary Philosophy]. Tōkyō 東京: Seidosha 青土社, pp. 46-60.

Tomoe, Kentarō巴健太郎. 2014. “Terebi dorama kara miru dansei dōseiaisha no egakarekata shakaigaku mediakenkyū kara miru dōseiai テレビドラマから見る男性同性愛者の描かれ方一 社会学・メディア研究から見る同性愛 [How Male Homosexuals are Shown in TV Series: Homosexuality from Sociological Media Studies].” Bachelor thesis, Keiō Gijuku Daigaku 慶応義 塾大学, Japan.

Trültzsch, Sascha. 2009. Kontextualisierte Medieninhaltsanalyse - Mit einem Beispiel zum Frauenbild in DDR-Familienserien. Wiesbaden: VS Verlag für Sozialwissenschaften.

Villarejo, Amy. 2007. "Materiality, Pedagogy, and the Limits of Queer Visibility." In George Haggerty and Molly McGarry, eds., A Companion to Lesbian, Gay, Bisexual, Transgender, and Queer Studies. Malden: Blackwell Publishing, pp. 389-403.

Wee, Darren. 2015. "Japan TV to Air First Lesbian Drama." Gaystarnews; October 23, 2015; online: https://www.gaystarnews.com/article/japan-tv-to-air-first-lesbian-drama/\#gs.k2gz81 (accessed: June 22, 2019).

Yamamoto, Nanako 山本菜々子. 2013. “Terebi ni utsuru sekusharitî — 'onē' no saki ni mitai mono テレビにうつるセクシャリティ—“オネエ”の先に観たいもの [Sexuality in Television What We Want to See after Onē].” Online: https://synodos.jp/society/4482 (accessed: March 3, 2019).

Yanagisawa, Masakazu 柳沢正和, Muraki Maki 村木真紀, and Gotō Jun'ichi 後藤純一. 2017. Shokuba no LGBT tokuhon: 'Ari no mama no jibun' de hatarakeru kankyō o mezashite 職場の LGBT 読本:「ありのままの自分」で働ける環境を目指して [Reader about LGBT in the Workplace: Aiming at an Environment Where You Can Work “Just As You Are"]. Tōkyō 東京: Jitsumu Kyōiku Shuppan 実務教育出版.

Yuen, Shu Min. 2011. "Last Friends, Beyond Friends: Articulating Non-Normative Gender and Sexuality on Mainstream Japanese Television.” Inter-Asia Cultural Studies, 12 (3), pp. 383400. 


\section{GLOSSARY $^{3}$}

\begin{tabular}{|c|c|c|}
\hline Abe Sadao & 阿部サダタ & Actor \\
\hline Amami Yuki & 天海祐希 & Actress \\
\hline Asano Taeko & 浅野妙子 & $\begin{array}{l}\text { Scriptwriter and producer of } \\
\text { TV series }\end{array}$ \\
\hline bishōnen & 美少年 & $\begin{array}{l}\text { Term describing beautiful } \\
\text { young men }\end{array}$ \\
\hline Boys Love & ボーイズ ラブ(BL) & $\begin{array}{l}\text { Manga genre depicting ro- } \\
\text { mantic and sexual relations } \\
\text { between men }\end{array}$ \\
\hline dorama & ドラマ & See: renzoku dorama \\
\hline Fuji Sumiko & 富司純子 & Actress \\
\hline gairaigo & 外来語 & Foreign language terms \\
\hline$g e i$ & ゲイ & (Male) homosexual, gay \\
\hline hōmu dorama & ホームドラマ & $\begin{array}{l}\text { Genre of TV series that fo- } \\
\text { cuses on the story of a family } \\
\text { and its members }\end{array}$ \\
\hline Horie Yuri & 堀江有里 & $\begin{array}{l}\text { Scholar of Gender Studies } \\
\text { and Religion }\end{array}$ \\
\hline Ishida Hikari & 石田ひかり & Actress \\
\hline Itō Ran & 伊藤蘭 & Actress \\
\hline Kawaguchi Kazuya & 河口和也 & Scholar of Queer Studies \\
\hline Keiser, Yuki & 雪カイザー & Blogger and PR-manager \\
\hline Kira kira hikaru & きらきらひかる & Movie: Twinkle \\
\hline kuīa & クイーア & Queer \\
\hline Kuroda Fukumi & 黒田福美 & Actress \\
\hline Makimura Asako & 牧村朝子 & Advocate for LGBT rights \\
\hline Mitsuhashi Junko & 三橋順子 & Scholar of Gender Studies \\
\hline Morisaki Win & 森崎ウィン & Actor \\
\hline Munakata Miki & 宗方美樹 & Advocate for LGBT rights \\
\hline Muraki Maki & 村木真紀 & $\begin{array}{l}\text { Advocate for LGBT rights, } \\
\text { Head of Nijiiro Diversity. }\end{array}$ \\
\hline Nagasaku Hiromi & 永作博美 & Actress \\
\hline Nagasawa Masami & 長澤まさみ & Actress \\
\hline Nakamura Aoi & 中村蒼 & Actress \\
\hline Nishikido Ryo & 錦戸亮 & Actor \\
\hline
\end{tabular}

\footnotetext{
${ }^{3}$ Please note that named characters from TV series and authors who publish in a language other than Japanese do not appear in the glossary.
} 
Nishimura Masahiko

Nonami Asa

okama

Okoge

Okuyama Yoshie

onabe

one-kyara

\section{Ōoku}

ore

Ōta Tōru

Otōto no otto

renzoku dorama

rezubian

Saitō Yuki

Sawamura Ikki

Shimizu Misa

Shinjuku Nichōme

shōjo

Suganuma Katsuhiko

Sugiura Ikuko

tachi/neko

Tamayama Tetsuji

Tamura Masakazu

tanin

Terrace House

tōjisha

Tokiwa Takako

Tomoe Kentarō
西村まさ彦

乃南アサ

オカマ

おこげ

奥山佳恵

オナベ

オネエキャラ

大奥

俺

大多亮

弟の夫

連続ドラマ

レズビアン

斉藤由貴

沢村一樹

清水美沙

新宿二丁目

少女

菅沼勝彦

杉浦郁子

タチ/永コ

玉山鉄二

田村正和

他人

テラスハウス

当事者

常盤貴子

巴健太郎
Actor

Author

(Derogative) term for gay men, feminine men

Movie: Fag Hag

Actress

(Derogative) term for masculine women, lesbians

Drag queen, male person cross-dressing as a woman usually to entertain an audience

TV series: The Inner Chambers

Self-referential pronoun, considered to be informal and masculine

Producer of TV series

TV series: My Brothers' Husband

Japanese format for TV series

Lesbian

Actress

Actor

Actress

District in Tokyo, famous for its gay bars

Manga genre aimed at girls and young women

Scholar of Queer Studies and Japanese Studies

Scholar of Gender Studies

Distinction of gendered roles in lesbian relationships

Actor

Actor

Unfamiliar person

TV series

Concerned person

Actress

Scholar 
Ueno Juri

watashi

yakuza

Yukawa Kazuhiko

Yuri
ヤクザ

上野樹里

私

遊川和彦

百合
Actress

Polite self-referential pronoun, used by different genders

Member of a Japanese organised crime syndicate Scriptwriter and producer of TV-Series

Manga genre depicting romantic and sexual relations between young women 